\title{
Kauniin dilemma
}

Laura Jetsu

\author{
Suo on kaunis. Toimittanut Kirsi Hakala. Käännökset Asta Ruokolainen, \\ Marjatta Liljeström ja Leevi Lehto. Maisema- ja eläinkuvat Jorma Luhta. \\ Kuva sivulla 155 sekä performanssikuvat Sanni Seppo. Graafinen suunnit- \\ telu Ritva Kovalainen. Maahenki Oy. Helsinki 1999. 268 s.
}

\section{Ilmoitettu kauneus}

Kolmannen kansainvälisen ympäristöestetiikan konferenssin (1998) alustuksista toimitetun julkaisun kannessa todetaan yksiselitteisesti: Suo on kaunis. Nimi on tekijöiden voimakas ja päämäärätietoinen kannanotto siihen pohdintaan, jota kirjassa käydään alusta loppuun saakka. Kysymys on kauneuden dilemmasta suhteessa suohon. Vaikka nimi kategorisuudessaan tuntuu antavan tilaa vain yhdenlaiselle tulkinnalle: suon kauneuden oivaltamiselle ja sen allekirjoittamiselle, se ei silti ole tyrmäävä. Se on pikemminkin eräällä tavalla vastaus kysymyksiin, jotka ovat koko ajan läsnä, mutta joita ei suoraan esitetä. Nimessä on kielestä tulevaa rytmistä viehätystä, jota mielikään ei vierasta. Ehkäpä nimi kuvastaakin sitä kielen ja mielen välistä sidosta, joihin muutamissa kirjoituksissa viitataan suokuvausten ja suosta käytettyjen ilmausten perimmäisinä merkityksinä. Jos näin on, nimi kertoo muuttuneesta tai vähintäänkin laajenevasta suon kokemisen ja merkitysten tulkinnasta.

Myös kirja on kaunis - ja sekin todetaan tekijöiden suulla jo saatesanoissa. Suo on kaunis -teos on nimenomaan kaunis esine. Ensimmäisiä kertoja kirjaa selaillessa sitä pohtii, miten se onkin niin kaunis. Miten jo pelkkä paperi houkuttelee koskettamaan ja avaamaan sivuja uudestaan ja uudestaan. Teos on typografialtaan huolellisesti harkittu, riittävän rikas ja vaihteleva olematta levoton. Kirja on vaikeasti tavanomaisiin luokituksiin asettuva. Tyypillisestä konferenssijulkaisusta se on astunut pitkähkön askeleen kuvateosten suuntaan, mutta kuvateos se ei ole. Suo on kaunis on mielestäni poikkeuksellisen onnistunut tekstin, kuvien, typografian ja painopaperin muodostama kokonaisuus, jossa kuvat eivät kuvita tekstiä eikä teksti selitä kuvia. Se on Puiden kansan (Kovalainen ja Seppo 1997, Oulu Pohjoinen) pikkusisar. Se on niin samanlainen, että sen tunnistaa samaan perheeseen kuuluvaksi, mutta niin erilainen, että sillä on oma persoonallisuutensa. Ritva Kovalaisen ja Sanni Sepon käden jälki on kirjan sivuilla hyvin tunnistettavissa. 


\section{Neuvoteltava kauneus}

Kirjan kansien väliin mahtuu paljon puhetta ja kuvia suosta. Sisältö noudattaa kuuliaisesti Suon estetiikka -konferenssin järjestystä. Liikkeelle lähdetään suopursusta. Vaaleansinisellä sivulla on yksinään Asser Tervasmäen teksti, joka on suurelle osalle suomalaisia tuttu Suopursu-tangon sanoituksena. Itselleni - myös konferenssiin osallistuneena - tuolta aukeamalta alkaa päässä soida Heikki Laitisen hiljaa voimistuva Suopursu-laulun äänimaailma ja suorastaan näen Reijo Kelan yhden miehen koreografian, jotka yhdessä loivat konferenssille sitä koko ajan leimanneen tunnemaiseman. Lukijalle nämä mieli- ja äänikuvat eivät tietystikään aukene, mutta jotain samaa jopa nöyrän yksinkertaista on tuossa ensimmäisessä sivussa: liikkeellelähdössä ilman selityksiä. Vasta sen jälkeen on sisällyksen, saatesanojen ja johdantolukujen vuoro.

Teos on jaettu artikkeleita kokoavien väliotsikoiden alle. Ratkaisu on hyvä, näin laaja sisältö pysyy hallinnassa ja jäsentyy lukijalle helpommin. Sisällysluettelossa väliotsikoita on enemmän kuin itse tekstissä ja luetteloa katsoessa hieman hämmästyy kesken kaiken ilmaantuvaa Lopuksi -otsikkoa, jonka jälkeen vielä kuitenkin seuraa melkoinen määrä luettavaa ja katsottavaa, kaikkiaan seitsemän artikkelia. Tekstien sisään on sijoitettu vaihtelevasti pieniä kuvia, mutta muuten kuvat ovat omina kokonaisuuksinaan, jolloin ne ovat selkeästi pääosassa ja saavat enemmän omaa elintilaa. Kuvajaksojen yhteyteen on otettu muutamia Aaro Hellaakosken suoaiheisia runoja. Pehmeäpintainen ja luonnonvalkoinen painopaperi tuo suokuviin tavallisista kuvateoksista poikkeavan tunnun. Kuvat menettävät osan tarkkapiirtoisuudestaan, mutta toisaalta pystyvät näin toteutettuina välittämään jotain olennaista kohteestaan, suon pehmeydestä ja ääriviivojen epätäsmällisyydestä.

Mistä teoksessa sitten puhutaan, kun puhutaan suosta. Johdanto-osan kaksi artikkelia määrittelevät sitä, mitä tuleman pitää ja keskustelevat itsessään ja keskenäänkin suon esteettisestä dilemmasta, kauneuden ja ankeuden kohtaamisesta. Toinen jakso tarjoaa tuhdin tietopaketin suon ekologiasta, mutta varsinkin jakson toisessa artikkelissa suuntaudutaan jo voimakkaasti pohtimaan tarkoitusta palvelevan mukautumisen kauneutta eli ekosysteemin estetiikkaa. Asiantuntijoillehan se on selvää ja kiitettävän hyvin he tämänkin kirjan sivuilla lukijalle muistuttavat, että luonnonympäristöjen estetiikasta puhuttaessa kysymys on paljon enemmästä kuin luonnonkauniin (sana itsessään on kammottava ja huono valinta, joka johdattaa ajattelemaan, että sen vastakohtana olisi luonnonruma, mutta käytössä yleinen), sievän tai ylipäätään vain kauniin jäljittämisestä luonnossa. Kaoottiseltakin vaikuttava ekosysteemi on esteettisesti stimuloiva, kun sitä arvostetaan sellaisenaan, omana tarkoituksenmukaisena kokonaisuutenaan. Silloin ei ole tarvettakaan lähteä hakemaan siitä samoja esteettisiä kokemuksia kuin jostain toisesta tutummasta, jo esteettiseksi mielletystä ympäristöstä.

\section{Myyttinen maisema}

Kiinnostavimpina jaksoina, sekä konferenssissa että kirjassa, pidin niitä, joissa puhutaan suon ja ihmisen suhteesta kulttuurihistoriassa ja taiteessa. En mitenkään halua arvottaa eri näkö- tai lähtökohtia suon tarkasteluun, nämä aihepiirit vain kiinnostavat itseäni eniten. Koen olevani suoihminen, soiden ympäröimänä kasvanut ja myös omat varhaisimmat suomieli- ja -muistikuvani liittyvät uhkaan, vaaraan ja pelkoon (tarkkaan ottaen ehkä pelotteluun), kenties sen vuoksi viivyn tai viihdyn juuri näissä artikkeleissa. Suo myyttisenä maisemana ja mielenmaisemana 
nousee kirjoituksissa voimakkaasti esiin. Voisi kuvitella, että suomalaisen sielun suhdetta suohon määrittää ennen muuta kalevalainen suon uhka: suo häpeällisen vajoamisen ja häviämisen konkreettisena alhona. Muutamat kirjoittajat toki viittaavatkin kuka suoremmin kuka epäsuoremmin suohon laulamiseen puhuessaan suosta masennuksen, nöyryytyksen, lopun - viime kädessä kuoleman - kuvana. Suohon kaiken kammon tyyssijana viitataan niin monta kertaa, että käsityksen täytyy olla hyvin yleinen eikä toki ainoastaan suomalainen.

Toinenkin eepos nousee parin kirjoittajan teksteissä esiin: varhainen anglosaksinen runoelma, Beowulf. Siihen liittyvät suokuvat ovat samansuuntaisia: suo on rumuuden, poikkeavuuden ja anomalian asuinsija. Hirviöt, paholaiset ja suoruumiit näyttävät olevan monen kansan perinteessä suon tavallista asujaimistoa matelijoiden ja sammakkoeläinten ohella. Suo äärimmäisenä maisemana, rajamaana, on luonteva koti kaikelle marginaaliselle. Pelkkä kauhu ja pelko ei riitä silti selittämään suon otetta ihmismielestä. Uhkan rinnalle tarvitaan suoja, rumuuden lisäksi kauneus ja ahdistuksen pariksi mielen rauha. Suon ja siihen liittyvien mahdollisuuksien ambivalenssista vasta syntyy kokonaisuus, jonka kiehtovuus riittää mielenkiinnon ylläpitoon.

Mutta useammin kuin kilpalaulannan nöyryyttävä piina näyttäytyy suomalaisten kirjoittajien teksteissä suon peräänantamattoman ja väkivaltaisen haltuunoton kautta kasvava uusi maan syntykertomus: "Alussa olivat suo, kuokka ja - Jussi”. Sekö se sittenkin on se perimmäinen tarve, ei antautuminen pelon, vihan, ankeuden tai edes kauneuden edessä, vaan haltuunotto millä hinnalla hyvänsä, huolimatta kaikista vastuksista, tai ehkä juuri niiden vuoksi. Kirjan kansainvälinen kirjoittajakaarti (suomalaisten ohella) keskustelee suon ekologiasta, suohon suhtautumisesta, suosta taiteen ja muotoilun lähteenä sekä suon kokemisesta, mutta vain suomalaiset pohtivat lopuksi (oikeastaan toimituksellisen ratkaisun vuoksi lopun jälkeen) suon hyötykäyttöä, tuotantoon ja teknologiaan liittyviä kysymyksiä - tuotannollista haltuunottoa. Eihän se todellisuudessa näin voi olla, tässä kirjassa se vain näyttäytyy tällä tavoin. Eikä ole tietysti mitenkään negatiivista, päinvastoin, pohtia esimerkiksi sitä, mitä tehdä turvetuotannosta vapautuvalle suolle, joka semmoisenaan on "ei mikään”. Tämä toinen, tuotannon jälkeinen haltuunotto, vaatii kenties enemmän kekseliäisyyttä ja peräänantamattomuutta kuin se ensimmäinen konsanaan.

\section{Luonnotonta luontoa}

Suo on kaunis sopii varmasti myös luonnonystävän käteen, vaikkei se klassinen luontokirja olekaan. Kirjan kuvamaailma on omanlaisensa. Kuvat on määritelty kahden nimikkeen alle: on maisema- ja eläinkuvia sekä performanssikuvia. Kaikkien yhteinen nimittäjä on suo. Edellisistä on totuttu käyttämään yleisnimeä luontokuvat, mutta mitä ovat performanssikuvat, jotka on otettu konferenssiin liittyneestä Sosiaalisuot -taidetapahtumasta Puohtiinsuolta. Onko niin, että ne eivät voi olla luontokuvia, koska niissä suoluonnon lisäksi esiintyy ihminen, luonnon "luonnottomin" tekijä, tai vähintäänkin ihmisen jättämä selkeä jälki. Ovatko ne saman mallin mukaan taidekuvia, koska niiden sisältönä on tuokioita performansseista, jotka toteutettiin taide -otsikon alla? Vai ovatko ne kulttuurikuvia, koska ihminen vaikutuksineen on niissä läsnä? Jos sanon, että ne ovat kuvia luonnon ja kulttuurin kohtaamisesta rakennan kliseisen ja keinotekoisen rajan, joka erottaa ihmisen luonnosta. Mutta lopettaako ihminen todella luonnon tulemalla mukaan sen kuvauksiin? Voiko se niin olla? Oli miten tahansa, kuvat ovat joka tapauksessa hienoja. Niitä kannattaa ja jaksaa katsella monta kertaa. Totesin jo edellä, että kirja on kaunis esine. Se on myös hyvää tekevä esine. Se tekee hyvää silmille, mielelle, käsille. Jos minun kuitenkin jostain syystä olisi pakko hävittää se, tiedän miten sen tekisin. Veisin sen suolle ja jättäisin sinne. Kävisin monta kertaa katsomassa, miten se hitaasti muuttuu - luonnoksi. 
Ei liene kovin helppoa ryhtyä rakentamaan tietoisesti jotain kokonaisuutta - varsinkaan kirjaa elämykseksi. Oletan, että tätä julkaisua on tehty elämysmielessä ja vieläpä onnistuneesti. Melko rohkeasti tekijät sen sanovatkin: "kirja kuvamaailmoineen jatkaa elämyksellisten suokokemusten sarjaa".

Mutta niin se vain on, elämys se on.

Suo on kaunis - ihan totta.

Laura Jetsu, FM

Joensuun yliopisto

laura.jetsu@joensuu.fi 